\title{
Synthesis of ferrocenesulfonyl chloride, key intermediate toward ferrocenesulfonamides
}

\author{
William Erb* \\ Min Wen \\ Thierry Roisnel \\ Florence Mongin \\ Univ Rennes, CNRS, ISCR (Institut des Sciences Chimiques de \\ Rennes)-UMR 6226, F-35000 Rennes, France. \\ william.erb@univ-rennes1.fr
}
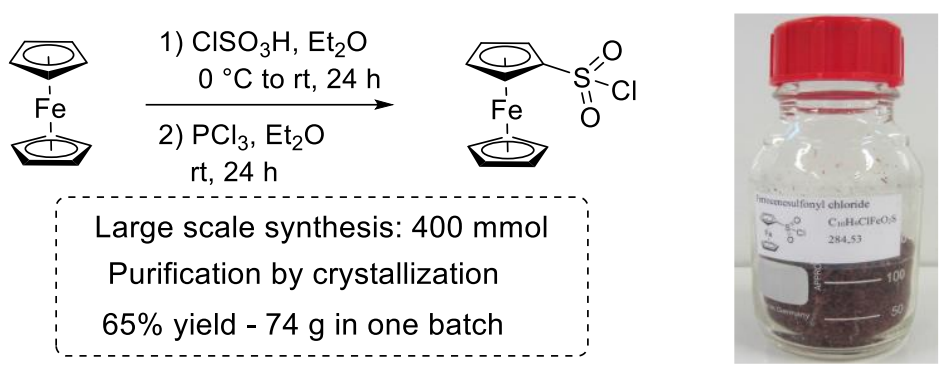

Abstract Ferrocenesulfonyl chloride is the key intermediate in the synthesis of ferrocenesulfonamides, a family of underexplored derivatives. Here, we report a one-pot synthesis of this compound able to easily deliver multigram quantities of product. While we also described an original protocol for the synthesis of ferrocenesulfonamides, we highlighted the reactivity difference between arene and ferrocene sulfonyl chlorides. Finally, we described an example of diastereoselective deprotolithiation of chiral ferrocenesulfonamides.

Key words Ferrocene, sulfonyl chloride, sulfonamide, scale-up diastereoselective deprotolithiation.

Although discovered seventy years ago, ferrocene still remains one of the most important organometallic scaffold with multiple applications in all areas of chemistry. ${ }^{1}$ This result from its threedimensional structure, reversible redox behavior, planar chirality properties and high stability in various conditions. While many ferrocene derivatives have been the focus of detailed studies, ferrocenesulfonamides remain a class of compounds barely explored although promising applications have already been reported. In 1992, Fabbrizzi reported the synthesis of an azamacrocycle substituted with a ferrocenesulfonamide and showed its ability to behave as a multielectron redox system. ${ }^{2} \mathrm{~A}$ decade later, in a series of publications, Roglans described the synthesis and characterization of polyunsaturated azamacrocycles. ${ }^{3}$ While 15 -membered triolefinic cycles were used as recyclable ligands in palladium-catalyzed Heck and Suzuki-Miyaura cross-couplings, ${ }^{3 a, 4}[2+2+2]$ cycloisomerizations were able to convert cyclic triynes into symmetrical hexasubstituted benzenes. ${ }^{5}$ More recently, Ganter reported original ferrocenesulfonamide-substituted $\mathrm{N}$-heterocyclic carbenes and their metal coordinating properties. ${ }^{6}$ Ferrocenesulfonamides can also be used as original substrates in organic synthesis. Indeed, while they can lead to ferrocenethiol by reduction toward sulfur-containing derivatives as described by Herberhold and Sato, ${ }^{7}$ Wurm described the anionic polymerization of a ferrocenesulfonylaziridine to reach original materials. ${ }^{8}$ The redox properties of ferrocenesulfonamide derivatives were also exploited either by Gao in a ferrous ions rhodamine-based sensor ${ }^{9}$ or Rochefort to reach a self-bleaching electrochromic device. ${ }^{10}$ In medicinal chemistry, Vâțâ reported the synthesis of penicillanic and cephalosporanic ferrocenesulfonamides and their biological evaluation against gram-positive bacterias. ${ }^{11}$ Finally, while few structures were sporadically reported in the literature, ${ }^{12}$ Ziegler and co-workers showed in a series of publications that ferrocenesulfonamides can led to the formation of hydrogen bonds. ${ }^{13}$

Whatever their applications, all the ferrocenesulfonamides described in these studies were prepared from bare ferrocene by sulfonation, chlorination and nucleophilic substitution (Scheme $1)$.

Scheme 1Step order toward ferrocenesulfonamides.

In 1955, Weinmayr was the first to report the unexpected sulfonation of ferrocene using concentrated sulfuric acid in acetic anhydride, proposed to slow down the competitive oxidation of ferrocene to ferricenium. ${ }^{14}$ After treatment with ammonia, the ammonium $\mathbf{1} \cdot \mathbf{N H}_{3}$ was isolated in a $78 \%$ yield. In 1957 , Nesmeyanov proposed to use the dioxane $\cdot \mathrm{SO}_{3}$ complex in dichloromethane and isolated ferrocenesulfonic acid either as its dihydrate $\left(\mathbf{1} \cdot \mathbf{2} \mathbf{H}_{2} \mathbf{O}\right)$ in a $62 \%$ yield or as a lead salt after treatment with lead carbonate. ${ }^{15}$ One year later, Pauson introduced the use of chlorosulfonic acid in acetic anhydride and isolated the same $\mathbf{1} \cdot 2 \mathbf{H}_{2} \mathbf{O}$ hydrate $\left(60 \%\right.$ yield). ${ }^{16}$ However, the work-up protocol involving an hydrolysis was described as hazardous. In 1969, Schlögl reported a modification of Pauson's isolation protocol and isolated $\mathbf{1}$ as its $p$-toluidinium salt (1 ptoluidine) in a $92 \%$ yield. ${ }^{17}$ Since then, most of the studies 
involving ferrocenesulfonic acid relied on the protocols described by Pauson and Schlögl.

Nesmeyanov was the first to describe the chlorination of both 1 and its lead salt using phosphorus trichloride toward ferrocenesulfonyl chloride 2 (69\% yield from 1).15, 18 Pauson further reported that the use of phosphorus pentachloride or thionyl chloride leads to the degradation of $\mathbf{1}$ while the use of a

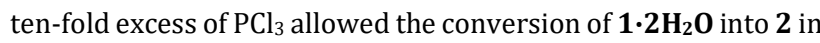
a $82 \%$ yield. ${ }^{16}$ Similarly, Schlögl employed a twenty-fold excess of $\mathrm{PCl}_{3}$ in the synthesis of $\mathbf{2}$ from $\mathbf{1} \boldsymbol{p}$-toluidine (94\% yield). In 1982 , Slocum proposed a two-step one-pot protocol to convert ferrocene into 2 by the sequential addition of chlorosulfonic acid and $\mathrm{PCl}_{3}$ in diethyl ether. ${ }^{19}$ Although the yield was lower than in the other approaches (23\%), this protocol does not require the isolation of $\mathbf{1}$, whether as its hydrate or salt. To the best of our knowledge, it was only in 2014 that oxalyl chloride was used as the chlorinating reagent in the synthesis of 2 . However, while Ganter described a $90 \%$ yield for this reaction using a two-fold excess of oxalyl chloride, ${ }^{6}$ Wurm reported a much lower $45 \%$ yield in similar reaction conditions. ${ }^{8}$

While all the syntheses of $\mathbf{1}$ and $\mathbf{2}$ employ similar reagents and conditions, the reported protocols to access ferrocenesulfonamides $\mathbf{3}$ are more diverse. Nesmeyanov and Pauson reported reactions at reflux in diethylamine and in an ammonia-acetone mixture, respectively $(75 \%$ yield for the latter), ${ }^{16,} 18$ while Schlögl used amino-esters in excess with or without pyridine at room temperature during 1 to 3 days (15 to $75 \%$ yield). ${ }^{17}$ The reactions conditions reported by Slocum are even smoother, using only 2 equivalents of amine at $0{ }^{\circ} \mathrm{C}$ for $2 \mathrm{~h}$, with moderate yields. ${ }^{19}$ However, during a study dedicated to the evaluation of ferrocenesulfonamides as electroactive tags for amino compounds, Koppang reported that Slocum's protocol only afforded the required products in low $(<10 \%)$ yields. Harsher reaction conditions using an acetone-aqueous sodium hydroxide mixture at $50{ }^{\circ} \mathrm{C}$ were next evaluated in the presence of tert-butylamine but only led to a $14 \%$ yield of the desired product. ${ }^{20}$ Both Vâțâ and Ma prepared ferrocenesulfonamides at the solvent reflux (ethyl acetate and diethyl ether, respectively) with moderate to good yields ${ }^{11}$, $12 \mathrm{~b}$ while Sato reported the synthesis of $\mathrm{N}, \mathrm{N}$-dimethylferrocenesulfonamide from $\mathbf{2}$ at room temperature using a tetrahydrofuran-water mixture of dimethylamine in a $87 \%$ yield. ${ }^{7 c}$ However, in this last case, the participation of water through hydrogen bonds might favor the substitution. Finally, the reaction of $\mathbf{2}$ with imidazole in the presence of potassium carbonate required heating at acetonitrile reflux ${ }^{6}$ while methylaziridine was able to react at $-30{ }^{\circ} \mathrm{C}$ in dichloromethane. ${ }^{8}$ It can be finally noticed that $1,1^{\prime}$ bis(ferrocenesulfonyl) chloride reacts in a stepwise manner with an excess of amine, the second substitution being slower than the first one. ${ }^{13 a}$

We recently described the synthesis of various polysubstituted ferrocenesulfonamides including original phosphine ligands for catalysis. ${ }^{21}$ However, while good yields were obtained in most of the reactions described, the overall efficiency was hampered by the low yielding synthesis of ferrocenesulfonyl chloride 2, prepared according to Slocum in a moderate $30 \%$ yield. With a view to developing a more efficient approach toward ferrocenesulfonamides, we decided to evaluate the use of 1,4diazabicyclo[2.2.2] octane-bis(sulfur dioxide) (DABSO) in the ferrocene series. Indeed, in a series of publications, Willis described the reaction of various organometallics with this surrogate of gaseous $\mathrm{SO}_{2}$ toward sulfonamides, ${ }^{22}$ sulfones, ${ }^{23}$ sulfoxides $^{24}$ and sulfinamides. ${ }^{25}$

Therefore, we reacted ferrocenyllithium, obtained by treating ferrocene by tert-butyllithium in the presence of potassium tertbutoxide, ${ }^{26}$ with DABSO. After conversion of the intermediate sulfinate to $\mathbf{2}$ using sulfuryl chloride, the addition of pyrrolidine afforded the desired ( $N$-pyrrolidino)sulfonylferrocene (3a) in a moderate $41 \%$ yield (Scheme 2). However, the reaction was found difficult to reproduce and we came to suspect that sulfuryl chloride might be incompatible with the oxidation-sensitive ferrocene. We therefore evaluated $N$-chlorosuccinimide ${ }^{27}$ as the chlorinating reagent but only isolated $\mathbf{3 a}$ in a reduced $21 \%$ yield. As ferrocene is known to be compatible with oxalyl chloride, we finally evaluated this last reagent, but only identified traces of the desired product 3a together with low amounts of the thiosulfonates 4-6 (see SI for a putative reaction mechanism and for the solid-state structures of $\mathbf{5}$ and $\mathbf{6}$ ). Therefore, while the DABSO route toward sulfonamides looks feasible in the ferrocene series, it would require a time-consuming careful evaluation of each step. Furthermore, the use of tert-butyllithium might be seen as a further limitation in view of both its pyrophoric character and limited availability in some countries.

1) tBuLi, tBuOK
2) DABSO
$\begin{aligned} & \text { 3) Chlorinating reagent } \\ & \text { 4) Pyrrolidine }\end{aligned}$ Scheme 2 Attempts to use DABSO in the synthesis of ferrocenesulfonamides.

Therefore, to progress toward a practical large scale synthesis of ferrocenesulfonyl chloride (2), we decided to focus our efforts on the one-pot protocol described by Slocum. ${ }^{19}$ We reasoned that the main difference between the high-yielding protocol of Pauson ${ }^{16}$ and the low-yielding from Slocum ${ }^{19}$ preferably lies in the sulfonation of ferrocene than in the chlorination step. While chlorosulfonic acid is employed in both protocols, the former used acetic anhydride proposed to reduced competitive oxidation of ferrocene ${ }^{14}$ while the latter used diethyl ether. Keen to avoid the use of large amounts of acetic anhydride, we decided to keep diethyl ether as solvent but at a lower concentration. Furthermore, to avoid the use of anhydrous solvent, we used a slight excess of chlorosulfonic acid (1.2 equiv instead of 1.1). This led to an increase of the formation of 2 on a $250 \mathrm{mmol}$ scale (46 g isolated, 64\% yield, Scheme 3). Our optimized conditions involve the dropwise addition of chlorosulfonic acid onto an icecooled solution of ferrocene in diethyl ether followed by $24 \mathrm{~h}$ stirring at room temperature. After addition of phosphorus trichloride, another $24 \mathrm{~h}$ stirring period is required before removal of volatiles under vacuum to give the crude product. While Slocum uses petroleum ether $\left(30-60{ }^{\circ} \mathrm{C}\right.$ boiling point fraction) to recrystallize 2 , we found that repeated trituration of the crude product with hot heptane, followed by crystallization, was a more efficient process. Pleasingly, we were able to conduct the reaction on a $400 \mathrm{mmol}$ scale with reproducible results 
(reaction done two times in 65 and 71\% yields; 74 and $80 \mathrm{~g}$ of 2 isolated, respectively).

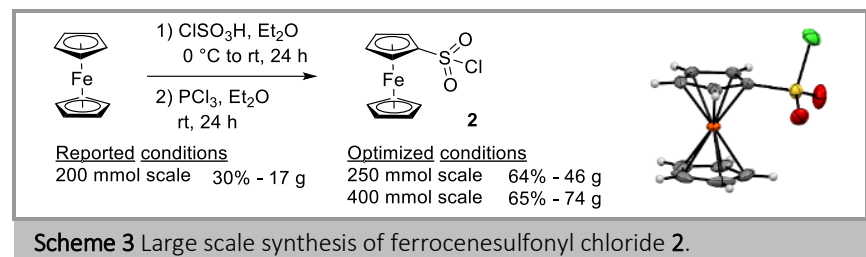

With the possibility to easily obtain large amounts of ferrocenesulfonyl chloride (2), we next focused our efforts on the synthesis of sulfonamides. Indeed, we were intrigued by the various reaction conditions described in the literature and by the report of Koppang on low-yielding smooth reaction conditions..$^{20}$ Therefore, we reacted $\mathbf{2}$ with different amines in reaction conditions inspired from the literature (Scheme 4). However, in our hands, most of the reaction conditions used only led to traces of expected product with various degrees of starting material recovery. The only successful conditions were the ones reported by Sato ${ }^{7 c}$ for the synthesis of $\mathbf{3 b}$ in a THF-water mixture $(91 \%$ yield on a $26 \mathrm{mmol}$ scale).

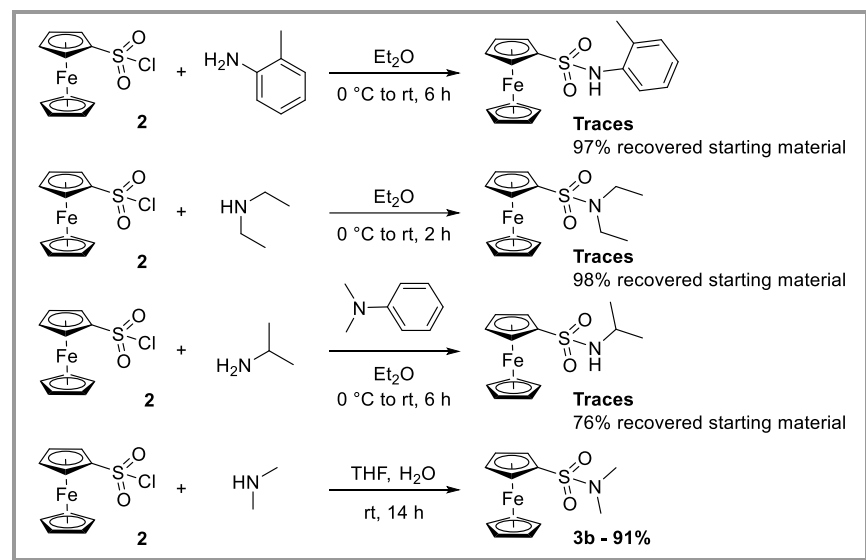

Scheme 4 Synthetic attempts toward ferrocenesulfonamides using protocols adapted from the literature. THF: tetrahydrofuran.

In search for harsher reaction conditions, 2 was reacted at $60^{\circ} \mathrm{C}$ with a three-fold excess of morpholine in chloroform at a 5 molar concentration. Pleasingly, ( $N$-morpholino)sulfonylferrocene (3c) was isolated in a $94 \%$ yield after only $30 \mathrm{~min}$ (Scheme 5 ). As we recognized that such high concentration might be incompatible with some solid amines, we repeated the reaction by adding a solution of morpholine, leading to a final 2.5 molar concentration, with similar results ( $96 \%$ yield). We next studied the scope of these new reaction conditions with various amines. Although pyrrolidine led to the sulfonamide $3 \mathbf{a}$ in a similar 95\% yield, it was found so reactive that the reaction needed to be done at a 2.5 molar concentration. For solubility reason, the same concentration was required when using Boc-protected piperazine to deliver $\mathbf{3 d}$ in $80 \%$ yield, together with the recovery of $15 \%$ of unreacted 2 . However, moving to other acyclic secondary amines resulted in a major drop of the yield, diethylamine leading to only $36 \%$ of $\mathbf{3 e}$ while diallylamine was found unreactive in our conditions toward compound $\mathbf{3 f}$. Although primary amines were more reactive, the reaction outcome was strongly influenced by their structure. Indeed, while $n$-butylamine afforded $3 \mathrm{~g}$ in a $94 \%$ yield, isopropylamine led to compound $\mathbf{3 h}$ in a $76 \%$ yield. A further drop in the yield was recorded with $(R)$ - $\alpha$-methylbenzylamine, even after $1 \mathrm{~h}$ of reaction (compound 3i, $44 \%$ yield), while only traces of the sulfonamide $\mathbf{3} \mathbf{j}$ were noticed using tert-butylamine. However, we found that increasing the reaction time favored the substitution as the sulfonamide $3 \mathbf{i}$ was isolated in $85 \%$ yield after $4 \mathrm{~h}$ at $60^{\circ} \mathrm{C}$. Aromatic amine such as $p$-toluidine was also found to be poorly reactive as compound $\mathbf{3 k}$ was only isolated in $15 \%$ yield. It should be noticed that the yields recorded are in good agreement with the nucleophilicity of the amine used. Indeed, Mayr reported the following order of reactivity for secondary and primary amines, respectively: pyrrolidine $>$ morpholine $>$ diethylamine and $n$-butylamine $>$ isopropylamine $>$ tert-butylamine. ${ }^{28}$

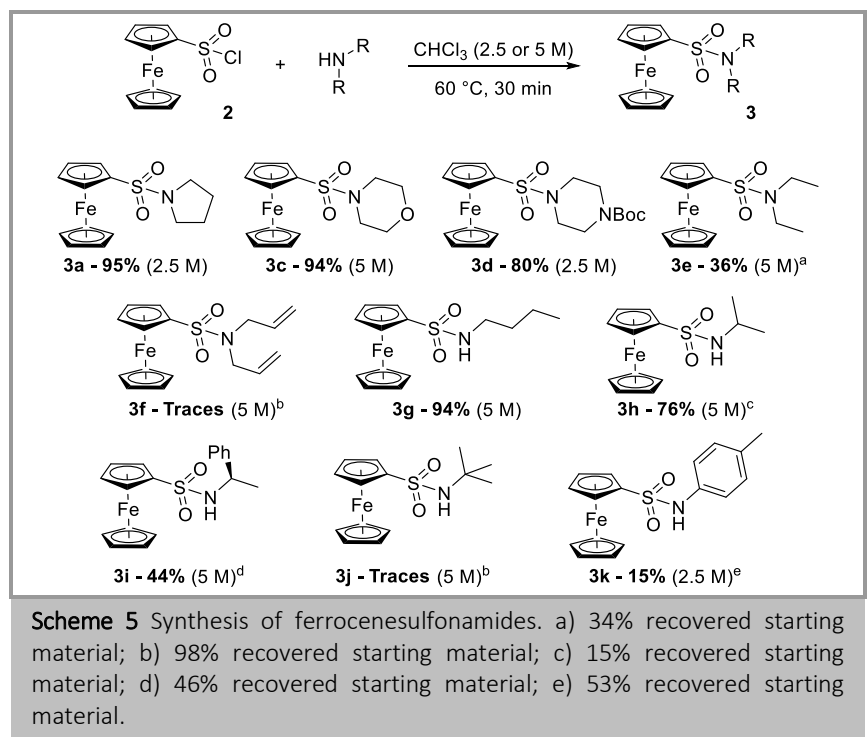

While the amine nucleophilicity plays an important role in the reaction outcome, we were also keen to compare the reactivity of ferrocenesulfonyl chloride (2) with more classical sulfonyl chloride such as the widely used $p$-tosyl chloride (Scheme 6). Under smooth reaction conditions, the latter was converted into the sulfonamide $\mathbf{7}$ in a quantitative way after only one hour at room temperature. However, the use of ferrocenesulfonyl chloride (2) required prolonged reaction time to deliver $\mathbf{3 b}$ in a $74 \%$ yield. The reactivity difference between 2 and $p$-tosyl chloride was further highlighted when they were reacted with diethylamine in our new reaction conditions. While $\mathbf{3 e}$ was formed in $36 \%$ yield, the sulfonamide 8 was obtained in a $95 \%$ yield after $30 \mathrm{~min}$. Although one could have suspected 2 to be less reactive than other aromatic sulfonyl chlorides, these results clearly show the difference between ferrocene and more classical aromatic compounds. This might result from both the electronrich nature of ferrocene and unfavorable steric parameters, the approach of the nucleophile opposite to the leaving being probably disfavored by the unsubstituted cyclopentadienyl ring as observed at the solid state (Scheme 3 ).

As previously observed by Ziegler, ${ }^{13 a}$, 13c hydrogen bonds can be observed at the solid state. For the ferrocenesulfonamides bearing a free $\mathrm{NH}$, a single string of hydrogen bonds linking all sulfonamide groups in compounds $\mathbf{3 h}$ and $\mathbf{3 k}$ was observed while two intermolecular hydrogen bonds link two sulfonamides in compound $\mathbf{3 g}$ (see SI). 


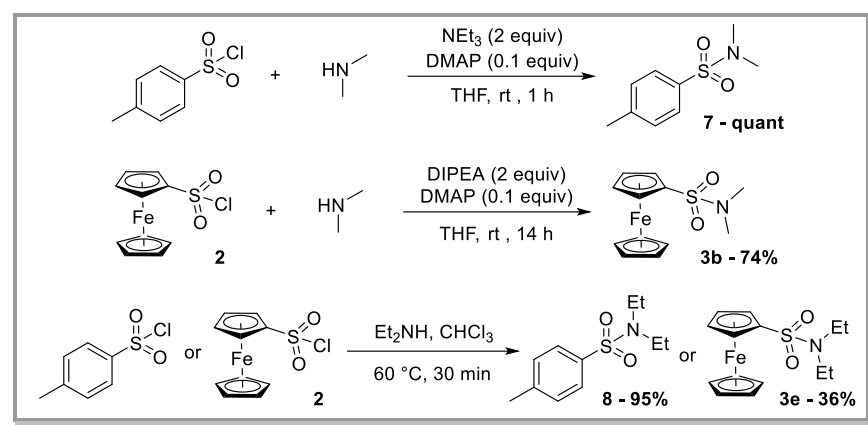

Scheme 6 Reactivity studies of $p$-tosyl chloride and ferrocenesulfonyl chloride 2. DIPEA: Diisopropylethylamine; DMAP: 4-(dimethylamino)pyridine; THF: tetrahydrofuran.

Finally, we were eager to evaluate the ability of chiral sulfonamides to direct a diastereoselective deprotolithiation in the ferrocene series (Scheme 7). ${ }^{29}$ Therefore, we reacted the sulfonamides $\mathbf{3 i}$ and $\mathbf{3 i}-\mathbf{M e}$ (obtained by deprotonation of $\mathbf{3 i}$ with $\mathrm{NaH}$ and subsequent trapping with methyl iodide) with $n$-BuLi in THF at $-80^{\circ} \mathrm{C}$ and added trimethylsilyl chloride after $1 \mathrm{~h}$ of contact. From 3i-Me, the disubstituted ferrocene $\mathbf{9}$ was obtained in $63 \%$ yield and a moderate $52 \%$ diastereoselective excess $(\mathrm{de})$, estimated from the ${ }^{1} \mathrm{H}$ NMR spectrum. While 2-dimensional NMR experiments suggested the $S_{p}$ configuration for the minor diastereoisomer (see SI), we found that the major isomer selectively crystallized from the mixture. The X-ray diffraction analysis allowed us to attribute the $R, R_{p}$ configuration to the major isomer, thus validating the $S_{p}$ configuration for the minor one, as suggested from NMR analysis. From $\mathbf{3 i}$, we isolated the two products 10-TMS $(71 \%, 48 \% d e)$ and $\mathbf{1 0}-\mathbf{H}(11 \%, 26 \% d e)$. For 10-TMS, although we were not able to growth crystals suitable for X-ray diffraction analysis, the ${ }^{1} \mathrm{H}$ NMR suggested the same configuration $\left(R, R_{p}\right)$ as for $\mathbf{9}$ while we propose the other configuration $\left(R, S_{p}\right)$ for the sulfonamide 10-H. Although the most used chiral directing groups can lead to higher yields and diastereoselectivties, ${ }^{30}$ these results highlight the ability of chiral sulfonamides to act in a similar way.

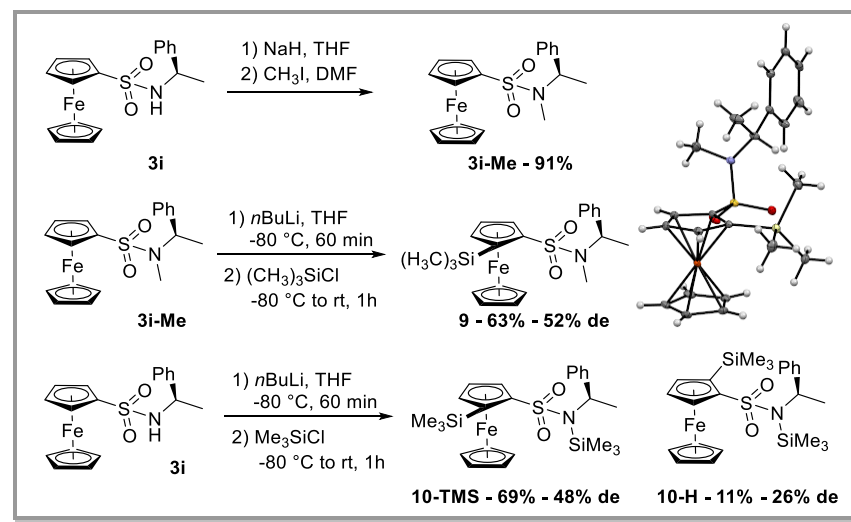

Scheme 7 Diastereoselective deprotolithiation of ferrocenesulfonamides 3 and 3i-Me. DMF: dimethylformamide; THF: tetrahydrofuran.

In conclusion, although we proved possible the use of DABSO to reach ferrocenesulfonamides, we focused our efforts on the large-scale synthesis of ferrocenesulfonyl chloride using a more classical route. Furthermore, we have described a new protocol for the synthesis of various ferrocenesulfonamides and identified its limitations in terms of both amines and ferrocenesulfonyl chloride reactivity. Finally, an example of diastereoselective deprotolithiation of chiral ferrocenesulfonamides was described with moderate but promising diastereoselectivity. Considering the already reported applications of ferrocenesulfonamides and our recent work toward their polysubstituted derivatives, we strongly believe that further important developments in this field could be expected.

General Considerations. Unless otherwise stated, all the reactions were performed under air using reagent grade solvents. Deprotolithiation experiments were performed under an argon atmosphere with anhydrous solvents using Schlenk technics and THF distilled over sodiumbenzophenone. Unless otherwise stated, all reagents were used without prior purification. $n$-Butyllithium was titrated before use. ${ }^{31} t \mathrm{BuOK}$ (99.99\% quality) was purchased from Sigma-Aldrich and used without further purification. Column chromatography separations were achieved on silica gel (40-63 $\mu \mathrm{m})$. For the purification of sulfonamides, $2 \%$ of $\mathrm{CHCl}_{3}$ was added to the eluant at the beginning of the purification to avoid the precipitation of compound on silica. All Thin Layer Chromatographies (TLC) were performed on aluminum backed plates pre-coated with silica gel (Merck, Silica Gel 60 F254). They were visualized by exposure to UV light. Melting points were measured on a Kofler bench. IR spectra were taken on a Perkin-Elmer Spectrum 100 spectrometer. ${ }^{1} \mathrm{H}$ and ${ }^{13} \mathrm{C}$ Nuclear Magnetic Resonance (NMR) spectra were recorded either (i) on a Bruker Avance III spectrometer at $300 \mathrm{MHz}$ and $75.4 \mathrm{MHz}$, respectively, or (ii) on a Bruker Avance III at $400 \mathrm{MHz}$ and $100 \mathrm{MHz}$, respectively or (iii) on a Bruker Avance III HD at $500 \mathrm{MHz}$ and $126 \mathrm{MHz}$, respectively. ${ }^{1} \mathrm{H}$ chemical shifts $(\delta)$ are given in ppm relative to the solvent residual peak and ${ }^{13} \mathrm{C}$ chemical shifts are relative to the central peak of the solvent signal. ${ }^{32} \mathrm{Cp}$ refers to the unsubstituted cyclopentadienyl ring of ferrocene. The numbering used in this experimental section is defined in Supporting information.

\section{Procedures}

\section{Ferrocenesulfonyl chloride (2)}

\section{[CAS Reg. No. 33010-70-7]}

Chlorosulfonic acid ( $31.9 \mathrm{~mL}, 55.9 \mathrm{~g}, 480 \mathrm{mmol}, 1.20$ equiv) was added dropwise to an ice-cold solution of ferrocene $(74.4 \mathrm{~g}, 400 \mathrm{mmol}, 1.00$ equiv) in diethyl ether (1.3 L). After addition, the dark reaction mixture was allowed to warm to rt and stirred for $24 \mathrm{~h}$. Phosphorus trichloride ( $80.4 \mathrm{~mL}, 126 \mathrm{~g}, 920 \mathrm{mmol}, 2.30$ equiv) was added dropwise to the reaction mixture at $\mathrm{rt}$ and the reaction mixture was then stirred at $\mathrm{rt}$ for $24 \mathrm{~h}$. Volatiles were removed under vacuum to give the crude product as dark solids which were scrapped with a spatula and kept under high vacuum for $10 \mathrm{~min}$. Heptane $(320 \mathrm{ml})$ was added and the mixture was heated at $90{ }^{\circ} \mathrm{C}$. After $10 \mathrm{~min}$ at this temperature, the red heptane was transferred to a hot flask which was allow to cool to rt. The extraction process was repeated until most of ferrocenesulfonyl chloride was extracted. Depending on the exact amount of heptane, the temperature, the contact time and the size of the solids, 2 to 4 extractions could be required. As ferrocenesulfonyl chloride is extracted, the initial solids evolve to a gummy blue-green paste which can be scrapped with a spatula for a better extraction. Caution: if a heat gun is used, pay attention to avoid hop spots as thermal decomposition might happen if the crude product becomes dry. Let the heptane solutions slowly cool to rt and filter the resulting red crystals using a sintered glass funnel (porosity 3 ). Wash the solids with a small amount of cold pentane and let it dry under high vacuum to give the title product 2 as a red solid (74.3 g, 65\%); $R_{f}=0.40$ (PET-EtOAc 90:10); $\mathrm{mp} 99-100^{\circ} \mathrm{C}$. CCDC 2063540.

Analytical data analogous to those reported previously. ${ }^{16}$

IR (film): 817, 831, 889, 1003, 1015, 1031, 1109, 1141, 1203, 1371, 1395 $1413,1734,2234,3113 \mathrm{~cm}^{-1}$.

${ }^{1} \mathrm{H} \mathrm{NMR} \mathrm{(500} \mathrm{MHz,} \mathrm{CDCl}_{3}$ ): $\delta=4.45$ (s, 5H, Cp), $4.60(\mathrm{t}, 2 \mathrm{H}, J=1.75 \mathrm{~Hz}, \mathrm{H} 3$ and $\mathrm{H} 4), 4.85(\mathrm{t}, 2 \mathrm{H}, J=1.75 \mathrm{~Hz}, \mathrm{H} 2$ and $\mathrm{H} 5)$.

${ }^{13} \mathrm{C} \mathrm{NMR}\left(126 \mathrm{MHz}, \mathrm{CDCl}_{3}\right): \delta=68.6(2 \mathrm{CH}, \mathrm{C} 2$ and $\mathrm{C} 5), 71.9(5 \mathrm{CH}, \mathrm{Cp}), 72.3$ (2CH, C3 and C4), 94.2 (C, $\mathrm{C} 1, \mathrm{C}-\mathrm{SO}_{2} \mathrm{Cl}$ ).

\section{General procedure for the synthesis of ferrocenesulfonamides.}

The required amine ( $18.0 \mathrm{mmol}, 3.00$ equiv) was added dropwise to a solution of compound 2 (1.70 g, $6.00 \mathrm{mmol}, 1.00$ equiv) in $\mathrm{CHCl}_{3}(1.2$ or $2.4 \mathrm{~mL}$ ) at $60^{\circ} \mathrm{C}$. After addition, the reaction mixture was stirred at the same temperature for 30 min before being cooled to rt. $\mathrm{HCl}(1 \mathrm{M}, 20 \mathrm{~mL})$ was added and the reaction mixture was extracted with $\mathrm{CH}_{2} \mathrm{Cl}_{2}$. The combined organic layers were dried over $\mathrm{MgSO}_{4}$, filtrated over cotton wool and concentrated under vacuum to give the product. This was 
purified by column chromatography over $\mathrm{SiO}_{2}$, using PET-EtOAc (proportions given for each product) to give the title product.

\section{(N-Pyrrolidino)sulfonylferrocene (3a)}

From ferrocene by using DABSO and sulfuryl chloride. $t$ BuLi $(1.5 \mathrm{M}, 6.60$ $\mathrm{mL}, 10.0 \mathrm{mmol}, 2.00$ equiv) was added dropwise to a solution of ferrocene (930 mg, $5.00 \mathrm{mmol}, 1.00$ equiv) and $t \mathrm{BuOK}(56.0 \mathrm{mg}, 0.50 \mathrm{mmol}, 0.10$ equiv) in THF ( $45 \mathrm{~mL})$ at $-80^{\circ} \mathrm{C}$. After addition, the reaction mixture was stirred at the same temperature for $1 \mathrm{~h}$ before being cannulated onto a suspension of DABSO (2.60 g, $10.0 \mathrm{mmol}, 2.20$ equiv) in THF ( $45 \mathrm{~mL})$ at $40{ }^{\circ} \mathrm{C}$. After addition, the reaction mixture was stirred at $-40{ }^{\circ} \mathrm{C}$ for $1 \mathrm{~h}$ Sulfuryl chloride $(0.90 \mathrm{~mL}, 1.50 \mathrm{~g}, 10.0 \mathrm{mmol}, 2.20$ equiv) was added dropwise and the reaction was warmed to $\mathrm{rt}$ and stirred for $1 \mathrm{~h}$ Pyrrolidine ( $4.20 \mathrm{~mL}, 3.60 \mathrm{~g}, 50.0 \mathrm{mmol}, 10.0$ equiv) was added dropwise and the reaction mixture was stirred at $\mathrm{rt}$ for $3 \mathrm{~h}$. $\mathrm{HCl}(1 \mathrm{M}, 50 \mathrm{~mL})$ was added and the reaction mixture was extracted with ethyl acetate. The combined organic layers were dried over $\mathrm{MgSO}_{4}$, filtrated over cotton wool and concentrated under vacuum to give the product. This was purified by column chromatography over $\mathrm{SiO}_{2}$, using PET-EtOAc $(80: 20)$ to give the product which was recrystallized to give the title product $\mathbf{3 a}$ as a yellow solid (658.0 mg, 41\%).

By following the general procedure, using pyrrolidine $(1.50 \mathrm{~mL})$ and $\mathrm{CHCl}_{3}(2.40 \mathrm{~mL}), 3 a$ was obtained after column chromatography (PETEtOAc, 50:50) as a yellow solid (1.81 g, 95\%); $\mathrm{R}_{\mathrm{f}}=0.25$ (PET-EtOAc 70:30); $\mathrm{mp} 216^{\circ} \mathrm{C}$. CCDC 2063541

IR (film): 656, 718, 755, 818, 832, 944, 959, 1002, 1045, 1077, 1113, 1135 $1149,1188,1217,1246,1259,1301,1327,1340,1412,1453,2859,2900$, $2960,3104 \mathrm{~cm}^{-1}$

${ }^{1} \mathrm{H}$ NMR $\left(300 \mathrm{MHz}, \mathrm{CDCl}_{3}\right): \delta=1.67-1.72\left(\mathrm{~m}, 4 \mathrm{H}, \mathrm{NCH}_{2} \mathrm{CH}_{2}\right), 3.13(\mathrm{t}, 4 \mathrm{H}, J=$ $\left.6.6 \mathrm{~Hz}, \mathrm{NCH}_{2} \mathrm{CH}_{2}\right), 4.37(\mathrm{t}, 2 \mathrm{H}, J=1.65 \mathrm{~Hz}, \mathrm{H} 3$ and $\mathrm{H} 4), 4.40(\mathrm{~s}, 5 \mathrm{H}, \mathrm{Cp}), 4.62$ $(\mathrm{t}, 2 \mathrm{H}, J=1.65 \mathrm{~Hz}, \mathrm{H} 2$ and $\mathrm{H} 5)$.

${ }^{13} \mathrm{C}$ NMR (75 MHz, CDCl 3$): \delta=25.3\left(2 \mathrm{CH}_{2}, \mathrm{NCH}_{2} \mathrm{CH}_{2}\right), 48.0\left(2 \mathrm{CH}_{2}, \mathrm{NCH}_{2}\right)$ 69.0 (2CH, C2 and C5), 70.6 (2CH, C3 and C4), 70.8 (5CH, Cp), 83.8 (C, C1, $\mathrm{C}$-SO 2 - $N$-pyrrolidino).

\section{$\underline{N}, N$-Dimethylferrocenesulfonamide (3b)}

[CAS Reg. No. 63453-42-9]

A solution of $\mathrm{NaOH}(4.80 \mathrm{~g}, 120 \mathrm{mmol}, 4.80$ equiv) in water $(20 \mathrm{~mL})$ was added to a solution of dimethylamine hydrochloride $(10.2 \mathrm{~g}, 125 \mathrm{mmol}$ 5.00 equiv) in water $(100 \mathrm{~mL})$. The resulting aqueous solution of dimethylamine was added to a solution of compound $2(7.33 \mathrm{~g}, 26.0 \mathrm{mmol}$ 1.00 equiv) in THF (150 mL) at rt. After addition, the reaction was stirred overnight at rt. Layers were separated and the aqueous layer was extracted with ethyl acetate. The combined organic layers were dried over $\mathrm{MgSO}_{4}$, filtrated over cotton wool and concentrated under vacuum to give the product. This was purified by recrystallization from heptane- $\mathrm{CHCl}_{3}$ to give the title product $\mathbf{3 b}$ as a yellow solid (6.93 g, 91\%); $\mathrm{R}_{\mathrm{f}}=0.50$ (PETEtOAc 70:30); mp $172{ }^{\circ} \mathrm{C}$. CCDC 2063542.

Analytical data analogous to those reported previously. ${ }^{7 c}$

IR (film): 655, 675, 701, 717, 754, 825, 845, 950, 1000, 1030, 1047, 1070 , $1108,1136,1165,1222,1264,1318,1336,1391,1446,1488,1580,2849$, $2960,3057,3418 \mathrm{~cm}^{-1}$.

${ }^{1} \mathrm{H}$ NMR (300 MHz, $\left.\mathrm{CDCl}_{3}\right): \delta=2.59\left(\mathrm{~s}, 6 \mathrm{H}, \mathrm{NMe}_{2}\right), 4.39$ (s, 2H, H3 and H4), $4.41(\mathrm{~s}, 5 \mathrm{H}, \mathrm{Cp}), 4.59$ (s, 2H, H2 and H5).

$\left.{ }^{13} \mathrm{C} \mathrm{NMR} \mathrm{(75} \mathrm{MHz,} \mathrm{CDCl}_{3}\right): \delta=38.0\left(2 \mathrm{CH}_{3}, \mathrm{NMe}_{2}\right), 69.2(2 \mathrm{CH}, \mathrm{C} 2$ and $\mathrm{C} 5)$, 70.7 (2CH, C3 and C4), 70.8 (5CH, Cp), 82.3 (C, C1, C-SO ${ }_{2} \mathrm{NMe}_{2}$ ).

\section{( $N$-Morpholino)sulfonylferrocene (3c)}

[CAS Reg. No. 63453-44-1]

By following the general procedure, using morpholine $(1.60 \mathrm{~mL})$ and $\mathrm{CHCl}_{3}(1.20 \mathrm{~mL}), 3 \mathrm{c}$ was obtained after column chromatography (PETEtOAc, 50:50) as an orange solid (1.90 g, 94\%); $\mathrm{R}_{\mathrm{f}}=0.13$ (PET-EtOAc 70:30); mp $208^{\circ} \mathrm{C}$. CCDC 2063543.

Analytical data analogous to those reported previously. ${ }^{33}$

IR (film): 656, 719, 755, 819, 943, 959, 1002, 1046, 1077, 1112, 1148, $1188,1246,1259,1327,1340,1412,1453,1719,2860,2901,2960,3104$ $\mathrm{cm}^{-1}$.

$\left.{ }^{1} \mathrm{H} \mathrm{NMR} \mathrm{(300} \mathrm{MHz,} \mathrm{CDCl} 3\right): \delta=2.90\left(\mathrm{t}, 4 \mathrm{H}, J=4.7 \mathrm{~Hz}, \mathrm{NCH}_{2}\right), 3.70(\mathrm{t}, 4 \mathrm{H}, J=$ $\left.4.4 \mathrm{~Hz}, \mathrm{OCH}_{2}\right), 4.42(\mathrm{~s}, 7 \mathrm{H}, \mathrm{H} 3, \mathrm{H} 4$ and $\mathrm{Cp}), 4.56(\mathrm{t}, 2 \mathrm{H}, J=1.65 \mathrm{~Hz}, \mathrm{H} 2$ and H5).

${ }^{13} \mathrm{C} \mathrm{NMR}\left(126 \mathrm{MHz}, \mathrm{CDCl}_{3}\right): \delta=46.0\left(2 \mathrm{CH}_{2}, \mathrm{NCH}_{2}\right), 66.1\left(2 \mathrm{CH}_{2}, \mathrm{OCH}_{2}\right), 69.3$ (2CH, C2 and C5), $70.9(5 \mathrm{CH}, \mathrm{Cp}), 71.0(2 \mathrm{CH}, \mathrm{C} 3$ and $\mathrm{C} 4), 82.2(\mathrm{C}, \mathrm{C} 1, C$ $\mathrm{SO}_{2}-N$-morpholino)
By following the general procedure, a solution of $\mathrm{N}$-Boc-piperazine ( 3.35 g) in $\mathrm{CHCl}_{3}(1.20 \mathrm{~mL})$ was added to compound 2 in $\mathrm{CHCl}_{3}(1.20 \mathrm{~mL}) . \mathbf{3 d}$ was obtained after column chromatography (PET-EtOAc, 80:20 to 70:30) as a yellow solid (2.09 g, 80\%); $\mathrm{R}_{\mathrm{f}}=0.46$ (PET-EtOAc 70:30); $\mathrm{mp}$ 194-196 ${ }^{\circ} \mathrm{C}$.

IR (film): 730, 768, 822, 859, 924, 999, 1018, 1054, 1093, 1126, 1146 $1166,1188,1251,1284,1307,1323,1348,1362,1391,1426,1453,1682$, $2865,2970 \mathrm{~cm}^{-1}$.

${ }^{1} \mathrm{H}$ NMR $\left(500 \mathrm{MHz}, \mathrm{CDCl}_{3}\right): \delta=1.40(\mathrm{~s}, 9 \mathrm{H}, t \mathrm{Bu}), 2.87(\mathrm{t}, 4 \mathrm{H}, J=5.0 \mathrm{~Hz}$ $\mathrm{CH}_{2} \mathrm{NSO}_{2}$ ), $3.46\left(\mathrm{t}, 4 \mathrm{H}, J=5.0 \mathrm{~Hz}, \mathrm{CH}_{2} \mathrm{NBoc}\right), 4.40(\mathrm{t}, 2 \mathrm{H}, J=1.9 \mathrm{~Hz}, \mathrm{H} 3$ and $\mathrm{H} 4), 4.41(\mathrm{~s}, 5 \mathrm{H}, \mathrm{Cp}), 4.55(\mathrm{t}, 2 \mathrm{H}, J=1.9 \mathrm{~Hz}, \mathrm{H} 2$ and $\mathrm{H} 5)$.

${ }^{13} \mathrm{C}$ NMR (75 MHz, $\left.\mathrm{CDCl}_{3}\right): \delta=28.4\left(3 \mathrm{CH}_{3}, t \mathrm{Bu}\right), 42.9\left(2 \mathrm{CH}_{2}, \mathrm{CH}_{2}-\mathrm{NBoc}\right)$ $45.9\left(2 \mathrm{CH}_{2}, \mathrm{CH}_{2} \mathrm{CH}_{2}-\mathrm{NBoc}\right), 69.2(2 \mathrm{CH}, \mathrm{C} 2$ and $\mathrm{C} 5), 70.9(5 \mathrm{CH}, \mathrm{Cp}), 71.0$ (2CH, C3 and C4), 80.4 (C, $\left.\mathrm{CMe}_{3}\right), 82.5\left(\mathrm{C}, \mathrm{C} 1, \mathrm{C}-\mathrm{SO}_{2} \mathrm{~N}\right)$.

\section{$\underline{N}, N$-Diethylferrocenesulfonamide (3e)}

[CAS Reg. No. 63495-23-8]

By following the general procedure, using diethylamine $(1.90 \mathrm{~mL})$ and $\mathrm{CHCl}_{3}(1.20 \mathrm{~mL}), 3 e$ was obtained after column chromatography (PETEtOAc, 90:10; $\mathrm{R}_{\mathrm{f}}=0.30$ ) as an orange solid $(701 \mathrm{mg}, 36 \%) ; \mathrm{mp} 88-89^{\circ} \mathrm{C}$.

Analytical data analogous to those reported previously. ${ }^{19}$

IR (film): 796, 814, 928, 1017, 1067, 1105, 1134, 1182, 1324, 1336, 1356, $1383,1412,1467,2937,2979,3108,3684 \mathrm{~cm}^{-1}$.

${ }^{1} \mathrm{H}$ NMR (500 MHz, $\left.\mathrm{CDCl}_{3}\right): \delta=1.08\left(\mathrm{t}, 6 \mathrm{H}, J=7.1 \mathrm{~Hz}, \mathrm{CH}_{2} \mathrm{Me}\right), 3.10(\mathrm{q}, 4 \mathrm{H}$ $J=7.1 \mathrm{~Hz}, \mathrm{CH}_{2} \mathrm{Me}$ ), 4.34 (s, 2H, H3 and $\mathrm{H} 4$ ), 4.40 (s, 5H, Cp), 4.59 (s, 2H, H2 and H5).

$\left.{ }^{13} \mathrm{C} \mathrm{NMR} \mathrm{(126} \mathrm{MHz,} \mathrm{CDCl}_{3}\right): \delta=14.0\left(2 \mathrm{CH}_{3}, \mathrm{Et}\right), 42.0\left(2 \mathrm{CH}_{2}, \mathrm{Et}\right), 68.5(2 \mathrm{CH}$, $\mathrm{C} 2$ and $\mathrm{C} 5$ ), 70.2 (2CH, C3 and C4), 70.7 (5CH, Cp), 87.7 (C, C1, C-SO ${ }_{2} \mathrm{NEt}_{2}$ ).

\section{$\mathrm{N}$-Butylferrocenesulfonamide (3g)}

By following the general procedure, using n-butylamine $(1.80 \mathrm{~mL})$ and $\mathrm{CHCl}_{3}(1.20 \mathrm{~mL}), 3 \mathrm{~g}$ was obtained after column chromatography (PETEtOAc, 80:20; $\left.\mathrm{R}_{\mathrm{f}}=0.43\right)$ as an orange solid $(1.82 \mathrm{~g}, 94 \%) ; \mathrm{mp} 102-103^{\circ} \mathrm{C}$. CCDC 2063544

IR (film): 741, 819, 845, 866, 909, 980, 1000, 1021, 1055, 1083, 1108, $1116,1144,1190,1225,1260,1320,1336,1391,1413,1426,1467,1659$, 2872, 2953, $3253 \mathrm{~cm}^{-1}$.

${ }^{1} \mathrm{H}$ NMR (300 MHz, $\mathrm{CDCl}_{3}$ ): $\delta=0.85(\mathrm{t}, 3 \mathrm{H}, J=7.3 \mathrm{~Hz}, \mathrm{Me}$ ), 1.28 (sext, $2 \mathrm{H}, J$ $=7.2 \mathrm{~Hz}, \mathrm{CH}_{2} \mathrm{Me}$ ), 1.41 (quint, $2 \mathrm{H}, J=7.2 \mathrm{~Hz}, \mathrm{CH}_{2} \mathrm{CH}_{2} \mathrm{Me}$ ), 2.91 (q, $2 \mathrm{H}, J=$ $\left.6.8 \mathrm{~Hz}, \mathrm{CH}_{2}\left(\mathrm{CH}_{2}\right)_{2} \mathrm{Me}\right), 4.06(\mathrm{t}, 1 \mathrm{H}, J=6.2 \mathrm{~Hz}, \mathrm{NH}), 4.37(\mathrm{t}, 2 \mathrm{H}, J=1.9 \mathrm{~Hz}, \mathrm{H} 3$ and $\mathrm{H} 4), 4.40(\mathrm{~s}, 5 \mathrm{H}, \mathrm{Cp}), 4.63(\mathrm{t}, 2 \mathrm{H}, J=1.9 \mathrm{~Hz}, \mathrm{H} 2$ and $\mathrm{H} 5)$.

${ }^{13} \mathrm{C}$ NMR (126 MHz, $\left.\mathrm{CDCl}_{3}\right): \delta=13.7\left(\mathrm{CH}_{3}, \mathrm{Bu}\right), 19.9\left(\mathrm{CH}_{2}, \mathrm{CH}_{2} \mathrm{Me}\right), 31.7$ $\left(\mathrm{CH}_{2}, \mathrm{CH}_{2} \mathrm{CH}_{2} \mathrm{Me}\right), 43.1\left(\mathrm{CH}_{2}, \mathrm{CH}_{2}\left(\mathrm{CH}_{2}\right)_{2} \mathrm{Me}\right), 68.7(2 \mathrm{CH}, \mathrm{C} 2$ and $\mathrm{C} 5), 70.5$ (2CH, C3 and C4), 70.9 (5CH, Cp), 87.8 (C, C1, C-SO ${ }_{2} \mathrm{NHBu}$ ).

\section{$\mathrm{N}$-Isopropylferrocenesulfonamide $(3 \mathrm{~h})$}

By following the general procedure, using isopropylamine $(1.60 \mathrm{~mL})$ and $\mathrm{CHCl}_{3}(1.20 \mathrm{~mL}), \mathbf{3 h}$ was obtained after column chromatography (PETEtOAc, $\left.80: 20 ; \mathrm{R}_{\mathrm{f}}=0.35\right)$ as an orange solid $(1.40 \mathrm{~g}, 76 \%) ; \mathrm{mp} 165-166^{\circ} \mathrm{C}$. CCDC 2063545

IR (film): 819, 879, 905, 1003, 1022, 1107, 1128, 1191, 1300, 1385, 1435 $1463,2959,3236 \mathrm{~cm}^{-1}$

${ }^{1} \mathrm{H}$ NMR (500 MHz, $\left.\mathrm{CDCl}_{3}\right): \delta=1.05(\mathrm{~d}, 6 \mathrm{H}, J=6.1 \mathrm{~Hz}, \mathrm{CHMe}$ ), 3.44 (oct, $1 \mathrm{H}, J=6.1 \mathrm{~Hz}, \mathrm{CHMe}$ ), 4.07 (br d, $1 \mathrm{H}, J=6.1 \mathrm{~Hz}, \mathrm{NH}), 4.37(\mathrm{~s}, 2 \mathrm{H}, \mathrm{H} 3$ and H4), 4.39 (s, 5H, Cp), 4.64 (s, 2H, H2 and H5).

${ }^{13} \mathrm{C} \mathrm{NMR}\left(126 \mathrm{MHz}, \mathrm{CDCl}_{3}\right): \delta=24.0\left(2 \mathrm{CH}_{3}, \mathrm{CHMe} 2\right), 46.1\left(\mathrm{CH}, \mathrm{CHMe}_{2}\right), 68.6$ (2CH, C2 and C5), 70.5 (2CH, C3 and C4), 70.9 (5CH, Cp), 89.1 (C, C1, C$\mathrm{SO}_{2} \mathrm{NHiPr}$ ).

\section{(R)- $N$-(1-phenylethyl)ferrocenesulfonamide (3i)}

By following the general procedure, using $(R)$ - $\alpha$-methylbenzylamine $(2.30$ $\mathrm{mL})$ and $\mathrm{CHCl}_{3}(1.20 \mathrm{~mL}), 3 \mathbf{i}$ was obtained after column chromatography (PET-EtOAc, 80:20; $\mathrm{R}_{\mathrm{f}}=0.28$ ) as an orange solid (981 mg, 44\%). When the reaction was performed for $4 \mathrm{~h}$ starting from $12.0 \mathrm{mmol}$ of compound 2 the title product $3 \mathbf{i}$ was obtained $(3.79 \mathrm{~g}, 85 \%)$; $\mathrm{mp} 111-112^{\circ} \mathrm{C}$

IR (film): 757, 783, 814, 836, 862, 920, 959, 1001, 1021, 1059, 1096, 1133, $1191,1318,1336,1388,1412,1437,1455,1495,1606,2988,3245 \mathrm{~cm}^{-1}$. ${ }^{1} \mathrm{H} \mathrm{NMR}\left(500 \mathrm{MHz}, \mathrm{CDCl}_{3}\right): \delta=1.41(\mathrm{~d}, 3 \mathrm{H}, J=6.6 \mathrm{~Hz}, \mathrm{Me}), 4.24(\mathrm{~s}, 1 \mathrm{H}, \mathrm{H} 3$ or H4), 4.30 (s, 1H, H3 or H4), 4.36 (s, 5H, Cp), 4.42 (s, 1H, H2 or H5), 4.45 (quint, $1 \mathrm{H}, J=6.6 \mathrm{~Hz}, \mathrm{CHMe}), 4.56(\mathrm{~s}, 1 \mathrm{H}, \mathrm{H} 2$ or $\mathrm{H} 5), 4.61(\mathrm{~d}, 1 \mathrm{H}, J=5.9 \mathrm{~Hz}$, $\mathrm{NH}$ ), 7.14 (d, 2H, $J=7.5 \mathrm{~Hz}, \mathrm{H} 2^{\prime}$ and H6'), 7.17-7.24 (m, 3H, H3', H4' and H5'). 
${ }^{13} \mathrm{C} \mathrm{NMR}\left(126 \mathrm{MHz}, \mathrm{CDCl}_{3}\right): \delta=23.8\left(\mathrm{CH}_{3}, \mathrm{Me}\right), 53.6(\mathrm{CH}, \mathrm{CHMe}), 68.4(\mathrm{CH}$ $\mathrm{C} 2$ or $\mathrm{C} 5), 69.0(\mathrm{CH}, \mathrm{C} 2$ or $\mathrm{C} 5), 70.4(\mathrm{CH}, \mathrm{C} 3$ or $\mathrm{C} 4), 70.5(\mathrm{CH}, \mathrm{C} 3$ or $\mathrm{C} 4)$ $70.8(5 \mathrm{CH}, \mathrm{Cp}), 88.6\left(\mathrm{C}, \mathrm{C} 1, \mathrm{C}-\mathrm{SO}_{2} \mathrm{NHR}\right), 126.3\left(2 \mathrm{CH}, \mathrm{C}^{\prime}\right.$ and $\left.\mathrm{C6}^{\prime}\right), 127.6$ (CH, C4'), 128.6 (2CH, C3' and C5'), 142.6 (C, C1').

$[\alpha]_{\mathrm{D}}=+50.0\left(c 0.01\right.$ in $\left.\mathrm{CHCl}_{3}\right)$.

\section{$\mathrm{N}$-(4-tolyl)ferrocenesulfonamide (3k)}

[CAS Reg. No. 115417-89-5]

By following the general procedure, a solution of $p$-toluidine $(1.93 \mathrm{~g})$ in $\mathrm{CHCl}_{3}(1.20 \mathrm{~mL})$ was added to compound 2 in $\mathrm{CHCl}_{3}(1.20 \mathrm{~mL}) .3 \mathbf{k}$ was obtained after column chromatography (PET-EtOAc, 90:10 to 80:20) as an orange solid (330 mg, 15\%); $\mathrm{R}_{\mathrm{f}}=0.17$ (PET-EtOAc 90:10); $\mathrm{mp} 174-175^{\circ} \mathrm{C}$. CCDC 2063546.

Analytical data analogous to those reported previously. ${ }^{34}$

IR (film): 773, 814, 889, 915, 1020, 1057, 1107, 1131, 1192, 1220, 1278, $1299,1326,1392,1457,1508,1614,2988,3236 \mathrm{~cm}^{-1}$.

${ }^{1} \mathrm{H}$ NMR (500 MHz, $\mathrm{CDCl}_{3}$ ): $\delta=2.28(\mathrm{~s}, 3 \mathrm{H}, \mathrm{Me}), 4.30(\mathrm{t}, 2 \mathrm{H}, J=1.9 \mathrm{~Hz}, \mathrm{H} 3$ and $\mathrm{H} 4), 4.37(\mathrm{~s}, 5 \mathrm{H}, \mathrm{Cp}), 4.49(\mathrm{t}, 2 \mathrm{H}, J=1.9 \mathrm{~Hz}, \mathrm{H} 2$ and $\mathrm{H} 5), 6.32(\mathrm{br} \mathrm{s}, 1 \mathrm{H}$, $\mathrm{NH}), 6.94\left(\mathrm{~d}, 2 \mathrm{H}, J=8.2 \mathrm{~Hz}, \mathrm{H} 2^{\prime}\right.$ and H6'), 7.04 (d, 2H, $J=8.2 \mathrm{~Hz}, \mathrm{H} 3^{\prime}$ and $\left.\mathrm{H} 5^{\prime}\right)$.

${ }^{13} \mathrm{C}$ NMR (126 MHz, $\left.\mathrm{CDCl}_{3}\right): \delta=21.0\left(\mathrm{CH}_{3}\right.$, tolyl), $69.0(2 \mathrm{CH}, \mathrm{C} 2$ and $\mathrm{C} 5)$, 70.6 (2CH, C3 and C4), 70.9 (5CH, Cp), 86.8 (C, C1, C-SO ${ }_{2} \mathrm{NH}$ tolyl), 122.7 (2CH, C2' and C6'), 129.9 (2CH, C3' and C5'), 134.3 (C, C1' or C4'), 135.4 (C, C1' or C4').

\section{$\underline{N, N, 4-T r i m e t h y l b e n z e n e s u l f o n a m i d e ~(7) ~}$}

[CAS Reg. No. 599-69-9]

A solution of dimethylamine in THF ( $2 \mathrm{M}, 15.0 \mathrm{~mL}, 30.0 \mathrm{mmol}, 1.50$ equiv) was added to a solution of $p$-tosyl chloride ( $3.81 \mathrm{~g}, 20.0 \mathrm{mmol}, 1.00$ equiv) and triethylamine ( $5.60 \mathrm{~mL}, 4.05 \mathrm{~g}, 40.0 \mathrm{mmol}, 2.00$ equiv) in THF (50 $\mathrm{mL}$ ). After addition, the reaction mixture was stirred at $\mathrm{rt}$ for $1 \mathrm{~h}$ before volatiles were removed under vacuum. The residue was dissolved in ethyl acetate and the organic phase was washed with $\mathrm{HCl}(1 \mathrm{M}), \mathrm{NaHCO}_{3}$ (sat.) dried over $\mathrm{MgSO}_{4}$, filtrated over cotton wool and concentrated under vacuum to give the title product 7 as a white solid (3.98 g, quant.); $\mathrm{R}_{\mathrm{f}}=$ 0.33 (PET-EtOAc 80:20); $\mathrm{mp} \mathrm{79-80}{ }^{\circ} \mathrm{C}$.

Analytical data analogous to those reported previously. ${ }^{35}$

IR (film): 721, 801, 814, 824, 954, 1054, 1091, 1159, 1188, 1264, 1290, $1309,1332,1381,1455,1472,1596,2875,3037 \mathrm{~cm}^{-1}$.

${ }^{1} \mathrm{H} \mathrm{NMR}\left(400 \mathrm{MHz}, \mathrm{CDCl}_{3}\right): \delta=2.43(\mathrm{~s}, 3 \mathrm{H}, \mathrm{Me}), 2.68\left(\mathrm{~s}, 6 \mathrm{H}, \mathrm{NMe}_{2}\right), 7.33(\mathrm{~d}$, $2 \mathrm{H}, J=8.2 \mathrm{~Hz}, \mathrm{H} 3$ and $\mathrm{H} 5), 7.65(\mathrm{~d}, 2 \mathrm{H}, J=8.2 \mathrm{~Hz}, \mathrm{H} 2$ and $\mathrm{H} 6)$.

$\left.{ }^{13} \mathrm{C} \mathrm{NMR} \mathrm{(100} \mathrm{MHz,} \mathrm{CDCl}_{3}\right): \delta=21.6\left(\mathrm{CH}_{3}, \mathrm{Me}\right), 38.1\left(2 \mathrm{CH}_{3}, \mathrm{NMe}_{2}\right), 127.9$ (2CH, C2 and C6), 129.7 (2CH, C3 and C5), $132.6\left(\mathrm{C}, \mathrm{C} 1, \mathrm{C}-\mathrm{SO}_{2} \mathrm{~N}\right), 143.6(\mathrm{C}$, C4).

\section{$\underline{N}, N$-Diethvl-4-methvlbenzenesulfonamide (8)}

[CAS Reg. No. 649-15-0]

By following the general procedure, using diethylamine $(1.90 \mathrm{~mL})$ and $\mathrm{CHCl}_{3}(1.20 \mathrm{~mL}), 8$ was obtained after column chromatography (PETEtOAc, 80:20 to 70:30) as a white solid (1.29g, 95\%); $R_{\mathrm{f}}=0.49$ (PET-EtOAc 80:20); mp $60-61^{\circ} \mathrm{C}$.

Analytical data analogous to those reported previously. ${ }^{36}$

IR (film): 713, 777, 815, 928, 1013, 1072, 1087, 1155, 1200, 1306, 1330, $1354,1375,1467,1495,1598,2936,2976 \mathrm{~cm}^{-1}$.

${ }^{1} \mathrm{H}$ NMR (400 MHz, $\left.\mathrm{CDCl}_{3}\right): \delta=1.11\left(\mathrm{t}, 6 \mathrm{H}, J=7.1 \mathrm{~Hz}, \mathrm{CH}_{2} \mathrm{Me}\right), 2.40(\mathrm{~s}, 3 \mathrm{H}$ $\mathrm{Me}$ ), 3.22 (q, $4 \mathrm{H}, J=7.1 \mathrm{~Hz}, \mathrm{CH}_{2} \mathrm{Me}$ ), 7.27 (d, $2 \mathrm{H}, J=8.3 \mathrm{~Hz}, \mathrm{H} 3$ and H5), $7.68(\mathrm{~d}, 2 \mathrm{H}, J=8.3 \mathrm{~Hz}, \mathrm{H} 2$ and $\mathrm{H} 6)$.

${ }^{13} \mathrm{C} \mathrm{NMR}\left(100 \mathrm{MHz}, \mathrm{CDCl}_{3}\right): \delta=14.3\left(2 \mathrm{CH}_{3}, \mathrm{Et}\right), 21.6\left(\mathrm{CH}_{3}, \mathrm{Me}\right), 42.1\left(2 \mathrm{CH}_{2}\right.$ Et), 127.2 (2CH, C2 and C6), 129.7 (2CH, C3 and C5), $137.6\left(\mathrm{C}, \mathrm{C} 1, \mathrm{C}-\mathrm{SO}_{2} \mathrm{~N}\right)$, 143.0 (C, C4).

\section{(R)- $N$-Methyl- $N$-(1-phenylethyl)ferrocenesulfonamide (3i-Me)}

Sodium hydride ( $60 \%$ in oil, $651 \mathrm{mg}, 15.0 \mathrm{mmol}, 3.00$ equiv) was added portionwise to a solution of compound $3 \mathbf{i}$ (1.84 g, $5.00 \mathrm{mmol}, 1.00$ equiv) in anhydrous THF (50 mL) under argon before being warmed to rt and stirred for $1 \mathrm{~h}$. The reaction mixture was cooled to $0^{\circ} \mathrm{C}$, methyl iodide $(965$ $\mu \mathrm{L}, 2.20 \mathrm{~g}, 15.0 \mathrm{mmol}, 3.00$ equiv) and dimethylformamide $(10 \mathrm{~mL})$ were added. After addition, the reaction was warmed to rt and stirred for $2 \mathrm{~h}$ $\mathrm{NH}_{4} \mathrm{Cl}$ (sat.) was added dropwise to the reaction mixture which was then extracted with ethyl acetate. The combined organic layers were washed with water, brine, dried over $\mathrm{MgSO}_{4}$, filtrated over cotton wool and concentrated under vacuum to give the crude product. This was purified by column chromatography over $\mathrm{SiO}_{2}$, using PET-EtOAc $(80: 20)$ to give the title product $3 \mathbf{i}-\mathbf{M e}$ as an orange solid $(1.75 \mathrm{~g}, 91 \%) ; \mathrm{R}_{\mathrm{f}}=0.59$ (PETEtOAc 80:20); $\mathrm{mp} 128-129^{\circ} \mathrm{C}$.

IR (film): 709, 767, 785, 827, 893, 913, 979, 1018, 1028, 1046, 1107, 1126, $1154,1188,1325,1336,1381,1413,1455,2982,3101 \mathrm{~cm}^{-1}$.

${ }^{1} \mathrm{H} \mathrm{NMR} \mathrm{(500} \mathrm{MHz,} \mathrm{CDCl}_{3}$ ): $\delta=1.28(\mathrm{~d}, 3 \mathrm{H}, J=7.0 \mathrm{~Hz}, \mathrm{CHMe}), 2.47(\mathrm{~s}, 3 \mathrm{H}$, $\mathrm{NMe})$, 4.37-4.39 (m, 2H, H3 and $\mathrm{H} 4), 4.43(\mathrm{~s}, 5 \mathrm{H}, \mathrm{Cp}), 4.62$ (quint, $1 \mathrm{H}, J=$ $1.2 \mathrm{~Hz}, \mathrm{H} 2$ or H5), 4.65 (quint, $1 \mathrm{H}, J=1.2 \mathrm{~Hz}, \mathrm{H} 2$ or H5), 5.16 (q, $1 \mathrm{H}, J=7.0$ $\mathrm{Hz}, \mathrm{CHMe}$ ), 7.23-7.25 (m, 1H, H4'), 7.28-7.31 (m, 4H, H2', H3', H5' and H6'). ${ }^{13} \mathrm{C} \mathrm{NMR}\left(126 \mathrm{MHz}, \mathrm{CDCl}_{3}\right): \delta(\mathrm{ppm}) 15.2\left(\mathrm{CH}_{3}, \mathrm{MeCHPh}\right), 28.3\left(\mathrm{CH}_{3}, \mathrm{NMe}\right)$, $54.9(\mathrm{CH}, \mathrm{CHMe}), 68.6(\mathrm{CH}, \mathrm{C} 2$ or $\mathrm{C} 5), 68.7(\mathrm{CH}, \mathrm{C} 2$ or $\mathrm{C} 5), 70.4(\mathrm{CH}, \mathrm{C} 3$ or C4), $70.5(\mathrm{CH}, \mathrm{C} 3$ or $\mathrm{C} 4), 70.9(5 \mathrm{CH}, \mathrm{Cp}), 87.8\left(\mathrm{C}, \mathrm{C} 1, \mathrm{C}-\mathrm{SO}_{2} \mathrm{~N}\right), 127.4(2 \mathrm{CH}$, C2' and $\mathrm{C6}^{\prime}$ ), 127.5 (CH, C4'), 128.4 (2CH, C3' and C5'), 140.4 (C, C1').

$[\alpha]_{\mathrm{D}}=+56.3\left(c 0.01\right.$ in $\left.\mathrm{CHCl}_{3}\right)$.

\section{(R)- $N$-Methyl- $N$-(1-phenylethyl)-2-}

\section{(trimethylsilyl)ferrocenesulfonamide (9)}

$n$ BuLi (1.4 M, $1.30 \mathrm{~mL}, 1.80 \mathrm{mmol}, 1.50$ equiv) was added dropwise to a solution of 3i-Me (460 mg, $1.20 \mathrm{mmol}, 1.00$ equiv) in anhydrous THF (6 $\mathrm{mL}$ ) at $-80^{\circ} \mathrm{C}$ under argon. After addition, the reaction mixture was stirred at the same temperature for $1 \mathrm{~h}$ before trimethylsilyl chloride $(228 \mu \mathrm{L}$, $195 \mathrm{mg}, 1.8 \mathrm{mmol}, 1.50$ equiv) was added. After addition, the reaction mixture was warmed to rt and stirred for a further $15 \mathrm{~min} . \mathrm{NH}_{4} \mathrm{Cl}$ (sat.) was added dropwise to the reaction mixture which was then extracted with ethyl acetate. The combined organic layers were washed with brine, dried over $\mathrm{MgSO}_{4}$, filtrated over cotton wool and concentrated under vacuum to give the crude product. This was purified by column chromatography over $\mathrm{SiO}_{2}$, using PET-EtOAc (10:1) to give the title product 9 (3.2:1 diastereoisomeric mixture) as an orange solid (345 mg, $63 \%, 52 \% d e$ ); $\mathrm{R}_{\mathrm{f}}=0.70$ (PET-EtOAc 10:1); mp 90-92 ${ }^{\circ} \mathrm{C}$. CCDC 2063549.

IR (film): 713, 760, 784, 827, 858, 929, 957, 988, 1029, 1046, 1109, 1125, $1139,1167,1189,1243,1280,1312,1329,1357,1385,1414,1450,1498$, 1686, 2948, $3092 \mathrm{~cm}^{-1}$.

In the NMR description below, * was used to spot the signals of the minor diastereoisomer.

${ }^{1} \mathrm{H} \mathrm{NMR} \mathrm{(500} \mathrm{MHz,} \mathrm{CDCl}_{3}$ ): $\delta=0.36$ and $0.37^{*}\left(\mathrm{~s}, 9 \mathrm{H}, \mathrm{FcSiMe}_{3}\right), 1.25$ and $1.42^{*}(\mathrm{~d}, 3 \mathrm{H}, J=7.1 \mathrm{~Hz}$, and $\mathrm{d}, 3 \mathrm{H}, J=6.9 \mathrm{~Hz}$, respectively; $\mathrm{CHMe}$ ), 2.46* and $2.51(\mathrm{~s}, 3 \mathrm{H}, \mathrm{NMe}), 4.32-4.33^{(*)}(\mathrm{m}, 1 \mathrm{H}, \mathrm{H} 3), 4.40^{*}$ and $4.41(\mathrm{~s}, 5 \mathrm{H}, \mathrm{Cp})$, $4.53^{*}$ and $4.54(\mathrm{t}, 1 \mathrm{H}, J=2.4 \mathrm{~Hz}, \mathrm{H} 4), 4.81^{*}$ and $4.82(\mathrm{dd}, 1 \mathrm{H}, J=2.3$ and 1.4 $\mathrm{Hz}$, and $\mathrm{dd}, 1 \mathrm{H}, J=2.2$ and $1.5 \mathrm{~Hz}$, respectively; $\mathrm{H} 5), 5.13$ and $5.18^{*}(\mathrm{q}, 1 \mathrm{H}$, $J=7.1 \mathrm{~Hz}$, and $\mathrm{q}, 1 \mathrm{H}, J=6.9 \mathrm{~Hz}$, respectively; $\mathrm{CHMe}), 7.23-7.31^{(*)}(\mathrm{m}, 5 \mathrm{H}$; H2', H3', H4', H5' and H6').

${ }^{13} \mathrm{C}$ NMR (126 MHz, $\left.\mathrm{CDCl}_{3}\right): \delta=1.1$ and $1.2^{*}\left(3 \mathrm{CH}_{3}, \mathrm{SiMe}_{3}\right), 15.0$ and $16.0^{*}$ $\left(\mathrm{CH}_{3}, \mathrm{MeCHPh}\right), 28.4$ and $28.6^{*}\left(\mathrm{CH}_{3}, \mathrm{NMe}\right), 54.2$ and $54.6^{*}(\mathrm{CH}, \mathrm{CHMe})$, 70.9 and $71.0^{*}(5 \mathrm{CH}, \mathrm{Cp}), 72.3$ and $72.5^{*}(\mathrm{CH}, \mathrm{C} 5), 72.6$ and $72.7^{*}(\mathrm{CH}, \mathrm{C} 4)$ 73.0 and 73.3* (C, C2, $\mathrm{C}$-SiMe 3 ), 77.4 and 77.4* (CH, C3), 93.5 and 93.5* (C, $\left.\mathrm{C} 1, \mathrm{C}-\mathrm{SO}_{2} \mathrm{~N}\right), 127.5^{(*)}$ and $128.4^{(*)}\left(5 \mathrm{CH}, \mathrm{C} 2^{\prime}, \mathrm{C} 3^{\prime}, \mathrm{C} 4^{\prime}, \mathrm{C} 5^{\prime}\right.$ and $\left.\mathrm{C}^{\prime}\right), 140.1^{*}$ and $140.4\left(\mathrm{CH}, \mathrm{C} 1^{\prime}\right)$.

$[\alpha]_{\mathrm{D}}=+136.6\left(c 0.01\right.$ in $\left.\mathrm{CHCl}_{3}\right)$.

(R)- $N$-(1-phenylethyl)- $N, 2$-bis(trimethylsilyl)ferrocenesulfonamide (10-TMS) and (R)- N-(1-phenylethyl)-2(trimethylsilyl)ferrocenesulfonamide (10-H)

$n$ BuLi (1.4 M, $2.60 \mathrm{~mL}, 3.60 \mathrm{mmol}, 3.00$ equiv) was added dropwise to a solution of $3 \mathbf{i}$ ( $443 \mathrm{mg}, 1.20 \mathrm{mmol}, 1.00$ equiv) in anhydrous THF ( $8 \mathrm{~mL}$ ) at $-80^{\circ} \mathrm{C}$ under argon. After addition, the reaction mixture was stirred at the same temperature for $1 \mathrm{~h}$ before trimethylsilyl chloride $(457 \mu \mathrm{L}, 391$ mg, 3.60 mmol, 3.00 equiv) was added. After addition, the reaction mixture was warmed to rt and stirred for a further $15 \mathrm{~min} . \mathrm{NH}_{4} \mathrm{Cl}$ (sat.) was added dropwise to the reaction mixture which was then extracted with ethyl acetate. The combined organic layers were washed brine, dried over $\mathrm{MgSO}_{4}$, filtrated over cotton wool and concentrated under vacuum to give the crude product. This was purified by column chromatography over $\mathrm{SiO}_{2}$, using PET-EtOAc (15:1). The title product 10-TMS $2.8: 1$ diastereoisomeric mixture) was isolated as an orange solid (427 mg, 69\%, $48 \%$ de); $\mathrm{R}_{\mathrm{f}}=0.66$ (PET-EtOAc $15: 1$ ); $\mathrm{mp} 127-130{ }^{\circ} \mathrm{C}$.

IR (film): 750, 784, 822, 837, 907, 970, 1003, 1025, 1042, 1068, 1101, $1122,1136,1190,1245,1281,1315,1381,1410,1448,1498,2956 \mathrm{~cm}^{-1}$.

In the NMR description below, * was used to spot the signals of the minor diastereoisomer.

${ }^{1} \mathrm{H}$ NMR (500 MHz, $\mathrm{CDCl}_{3}$ ): $\delta=0.11^{*}$ and 0.14 (s, 9H, $\mathrm{NSiMe}_{3}$ ), $0.30^{*}$ and 0.31 (s, $\left.9 \mathrm{H}, \mathrm{FcSiMe}_{3}\right), 1.17$ and $1.73^{*}(\mathrm{~d}, 3 \mathrm{H}, J=7.2 \mathrm{~Hz}$, and d, $3 \mathrm{H}, J=6.9 \mathrm{~Hz}$, respectively; $\mathrm{CHMe}$ ), 4.28* and 4.33 (dd, $1 \mathrm{H}, J=2.4$ and $1.4 \mathrm{~Hz}$, respectively; $\mathrm{H} 3), 4.42^{*}$ and $4.42(\mathrm{~s}, 5 \mathrm{H}, \mathrm{Cp}), 4.55$ and $4.57^{*}(\mathrm{t}, 1 \mathrm{H}, J=2.4$ $\mathrm{Hz}, \mathrm{H} 4), 4.59^{*}$ and $4.69(\mathrm{q}, 1 \mathrm{H}, J=6.9 \mathrm{~Hz}$, and $\mathrm{q}, 1 \mathrm{H}, J=7.2 \mathrm{~Hz}$, respectively; $\mathrm{CHMe}$ ) 4.79 and $4.92^{*}(\mathrm{dd}, 1 \mathrm{H}, J=2.4$ and $1.4 \mathrm{~Hz}$, and $\mathrm{dd}, 1 \mathrm{H}, J=2.3$ and 
$1.4 \mathrm{~Hz}$, respectively; $\mathrm{H} 5), 7.01^{*}$ and $7.48(\mathrm{~d}, 2 \mathrm{H}, J=7.5 \mathrm{~Hz}$, and $\mathrm{d}, 2 \mathrm{H}, J=$ $8.1 \mathrm{~Hz}$, respectively; $\mathrm{H} 2^{\prime}$ and $\left.\mathrm{H}^{\prime}\right), 7.10-7.12^{*}$ and $7.30(\mathrm{~m}, 2 \mathrm{H}$, and $\mathrm{t}, 2 \mathrm{H}$, $=7.5 \mathrm{~Hz}$, respectively; $\mathrm{H}^{\prime}$ and $\left.\mathrm{H} 5^{\prime}\right), 7.10-7.12^{*}$ and $7.22(\mathrm{~m}, 1 \mathrm{H}$, and $\mathrm{t}, 1 \mathrm{H}$ $J=7.5 \mathrm{~Hz}$, respectively; $\mathrm{H}^{\prime}$ )

${ }^{13} \mathrm{C}$ NMR (126 MHz, $\left.\mathrm{CDCl}_{3}\right): \delta=1.1^{*}$ and $1.1\left(3 \mathrm{CH}_{3}, \mathrm{FCSi} M e_{3}\right), 3.1^{*}$ and 3.2 $\left(3 \mathrm{CH}_{3}, \mathrm{NSiMe}_{3}\right), 18.3$ and $20.2 *\left(\mathrm{CH}_{3}, \mathrm{MeCHPh}\right), 53.7$ and $54.0^{*}(\mathrm{CH}, \mathrm{CHMe})$ 70.9 and $71.0^{*}(5 \mathrm{CH}, \mathrm{Cp}), 72.1$ and $72.2^{*}(\mathrm{CH}, \mathrm{C} 5), 72.9^{*}$ and $72.9(\mathrm{CH}, \mathrm{C} 4)$ 75.1 and $75.3\left(\mathrm{C}, \mathrm{C} 2, \mathrm{C}-\mathrm{SiMe}_{3}\right), 77.0$ and $77.3^{*}(\mathrm{CH}, \mathrm{C} 3), 94.2^{*}$ and $94.8(\mathrm{C}$ $\left.\mathrm{C} 1, \mathrm{C}_{-} \mathrm{SO}_{2} \mathrm{~N}\right), 126.7^{*}$ and $127.2\left(2 \mathrm{CH}, \mathrm{C}^{\prime}\right.$ and $\left.\mathrm{C}^{\prime}\right), 126.8^{*}$ and $127.0\left(\mathrm{CH}^{\prime}\right.$ C4'), 128.1* and 128.2 (C3' and C5'), 142.3 and $142.6^{*}\left(\mathrm{C}, \mathrm{C}^{\prime}\right.$ ').

$[\alpha]_{\mathrm{D}}=+111.2\left(c 0.01\right.$ in $\left.\mathrm{CHCl}_{3}\right)$

The title product 10-H (1.7:1 diastereoisomeric mixture) was similarly isolated as an orange oil (59.0 mg, 11\%, 26\% de); $\mathrm{R}_{\mathrm{f}}=0.15$ (PET-EtOAc 15:1)

IR (film): 731, 755, 782, 822, 910, 948, 966, 1002, 1041, 1068, 1084, 1108, $1119,1147,1191,1245,1319,1377,1411,1455,1495,1605,2955,3274$ $\mathrm{cm}^{-1}$.

In the NMR description below, * was used to spot the signals of the minor diastereoisomer.

$\left.1 \mathrm{H} \mathrm{NMR} \mathrm{(500} \mathrm{MHz,} \mathrm{CDCl}_{3}\right): \delta=0.28$ and $0.37^{*}\left(\mathrm{~s}, 9 \mathrm{H}, \mathrm{FcSiMe}_{3}\right), 1.29^{*}$ and $1.46(\mathrm{~d}, 3 \mathrm{H}, J=6.9 \mathrm{~Hz}$, and $\mathrm{d}, 3 \mathrm{H}, J=6.7 \mathrm{~Hz}$, respectively; $\mathrm{CHMe}), 4.23$ and 4.33-4.34* (dd, $1 \mathrm{H}, J=2.4$ and $1.4 \mathrm{~Hz}$, and $\mathrm{m}, 1 \mathrm{H}$, respectively; $\mathrm{H} 3$ ), 4.34 and $4.38 *(\mathrm{~s}, 5 \mathrm{H}, \mathrm{Cp}), 4.41 *$ and 4.46 (quint, $1 \mathrm{H}, J=7.3 \mathrm{~Hz}$, and quint, $1 \mathrm{H}$, $=6.7 \mathrm{~Hz}$, respectively; $\mathrm{CHMe}), 4.33-4.34$ and $4.50^{*}(\mathrm{~m}, 1 \mathrm{H}$, and $\mathrm{t}, 1 \mathrm{H}, \mathrm{J}=2.4$ $\mathrm{Hz}$, respectively; $\mathrm{H} 4), 4.58$ and $4.81^{*}(\mathrm{dd}, 1 \mathrm{H}, J=2.3$ and $1.5 \mathrm{~Hz}$, and $\mathrm{dd}$ $1 \mathrm{H}, J=2.2$ and $1.4 \mathrm{~Hz}$, respectively; $\mathrm{H} 5), 7.00-7.02$ and $7.22-7.25^{*}(\mathrm{~m}, 2 \mathrm{H}$ H2' and H6'), 7.15-7.19 and 7.22-7.25* (m, 1H, H4'), 7.15-7.19 and 7.287.32* (m, 2H; H3' and H5').

${ }^{13} \mathrm{C}$ NMR (126 MHz, $\left.\mathrm{CDCl}_{3}\right): \delta=0.8$ and $1.0^{*}\left(3 \mathrm{CH}_{3}, \mathrm{FcSi} M e_{3}\right), 23.2^{*}$ and $24.0\left(\mathrm{CH}_{3}, \mathrm{MeCHPh}\right), 53.2 *$ and $53.6(\mathrm{CH}, \mathrm{CHMe}), 70.8$ and $70.9 *(5 \mathrm{CH}, \mathrm{Cp})$ 71.8 and $72.2^{*}(\mathrm{CH}, \mathrm{C} 4), 71.8$ and $72.4^{*}\left(\mathrm{C}, \mathrm{C} 2, \mathrm{C}-\mathrm{SiMe}_{3}\right), 73.6^{*}$ and 73.8 $(\mathrm{CH}, \mathrm{C} 5), 77.8$ and $77.9^{*}(\mathrm{CH}, \mathrm{C} 3), 92.6$ and $92.9^{*}\left(\mathrm{C}, \mathrm{C} 1, \mathrm{C}-\mathrm{SO}_{2} \mathrm{~N}\right), 126.3$ and 126.3* (2CH, C2' and $\mathrm{C6}^{\prime}$ '), 127.6 and 127.6* $\left(\mathrm{CH}, \mathrm{C}^{\prime}\right), 128.6$ and $128.7^{*}$ (C3' and C5'), 142.4 and $142.9^{*}$ (C, C1').

$[\alpha]_{\mathrm{D}}=+43.7\left(c 0.01\right.$ in $\left.\mathrm{CHCl}_{3}\right)$.

\section{Funding Information}

This work was supported by the Agence Nationale de la Recherche (Ferrodance project) and the Université de Rennes 1.

\section{Acknowledgment}

We thank Rennes Métropole and the Fonds Européen de Développement Régional (FEDER; D8 VENTURE Bruker AXS diffractometer).

\section{References}

(1) (a) Ferrocenes: Homogeneous Catalysis, Organic Synthesis, Materials Science, Togni, A.; Hayashi, T., Eds. VCH: Weinheim, 1995; (b) Ferrocenes: Ligands, Materials and Biomolecules, Štěpnička, P., Ed. Wiley: Chichester, 2008; (c) Chiral Ferrocenes in Asymmetric Catalysis, Dai, L.-X.; Hou, X.-L., Eds. Wiley-VCH: Weinheim, 2010; (d) Astruc, D. Eur. J. Inorg. Chem. 2017, 2017, 6; (e) Patra, M.; Gasser, G. Nat. Rev. Chem. 2017, 1, 0066; (f) Zhu, J. C.; Cui, D. X.; Li, Y. D.; Jiang, R.; Chen, W. P.; Wang, P. A. ChemCatChem 2018, 10, 907; (g) Singh, A.; Lumb, I.; Mehra, V.; Kumar, V. Dalton Trans. 2019, 48, 2840.

(2) (a) De Blas, A.; De Santis, G.; Fabbrizzi, L.; Licchelli, M.; Mangano, C.; Pallavicini, P. Inorg. Chim. Acta 1992, 202, 115; (b) De Santis, G.; Fabbrizzi, L.; Licchelli, M.; Mangano, C.; Pallavicini, P.; Poggi, A. Inorg. Chem. 1993, 32, 854.

(3) (a) Llobet, A.; Masllorens, E.; Rodríguez, M.; Roglans, A.; BenetBuchholz, J. Eur. J. Inorg. Chem. 2004, 2004, 1601; (b) Blanco, B.; Christensen, J.; Maurel, I.; Pleixats, R.; Serra, A.; Pla-Quintana, A.; Roglans, A.; Benet-Buchholz, J. Synthesis 2005, 2005, 374; (c) PlaQuintana, A.; Roglans, A.; de Julián-Ortiz, J. V.; Moreno-Mañas, M.; Parella, T.; Benet-Buchholz, J.; Solans, X. Chem. Eur. J. 2005, 11, 2689; (d) Pla-Quintana, A.; Torrent, A.; Dachs, A.; Roglans, A.; Pleixats, R.; Moreno-Mañas, M.; Parella, T.; Benet-Buchholz, J. Organometallics 2006, 25, 5612 .

(4) (a) Llobet, A.; Masllorens, E.; Moreno-Mañas, M.; Pla-Quintana, A.; Rodríguez, M.; Roglans, A. Tetrahedron Lett. 2002, 43, 1425; (b)
Masllorens, J.; Moreno-Mañas, M.; Pla-Quintana, A.; Roglans, A. Org Lett. 2003, 5, 1559; (c) Masllorens, J.; Bouquillon, S.; Roglans, A.; Hénin, F.; Muzart, J. J. Organomet. Chem. 2005, 690, 3822; (d) Masllorens, J.; González, I.; Roglans, A. Eur. J. Org. Chem. 2007, 2007, 158.

(5) Torrent, A.; González, I.; Pla-Quintana, A.; Roglans, A.; Moreno-Mañas, M.; Parella, T.; Benet-Buchholz, J. J. Org. Chem. 2005, 70, 2033.

(6) Jonek, M.; Makhloufi, A.; Rech, P.; Frank, W.; Ganter, C. J. Organomet. Chem. 2014, 750, 140.

(7) (a) Herberhold, M.; Nuyken, 0;; P.öhlmann, T. J. Organomet. Chem. 1995, 501, 13; (b) Nagahora, N.; Ogawa, S.; Kawai, Y.; Sato, R. Tetrahedron Lett. 2002, 43, 5825; (c) Hiroki, M.; Satoshi, 0.; Noriyoshi, N.; Yasushi, K.; Ryu, S. Bull. Chem. Soc. Jpn. 2005, 78, 2026; (d) Nagahora, N.; Ogawa, S.; Kawai, Y.; Sato, R. Tetrahedron Lett. 2005, $46,4157$.

(8) Homann-Müller, T.; Rieger, E.; Alkan, A.; Wurm, F. R. Polym. Chem. 2016, 7, 5501.

(9) OuYang, H.; Gao, Y.; Yuan, Y. Tetrahedron Lett. 2013, 54, 2964.

(10) Gélinas, B.; Das, D.; Rochefort, D. ACS Appl. Mater. Interfaces 2017, 9, 28726.

(11) Simionescu, C.; Lixandru, T.; Scutaru, D.; Vâță, M. J. Organomet. Chem. 1985, 292, 269

(12) (a) Besenyei, G.; Párkányi, L.; Németh, S.; Simándi, L. I. J. Organomet. Chem. 1998, 563, 81; (b) Li, M.; Bai, Y.; Lu, J.; Yang, B.; Zhu, K.; Ma, H. J. Organomet. Chem. 2001, 637-639, 738; (c) Yang, Y. T.; Yang, B. Q.; Li, M.; Ning, W.; Lu, Z. H. Synth. Commun. 2008, 38, 530; (d) Yue, K.; Zhuo, F.; Zhai, G.; Hou, L.; Hou, Y.; Yin, B.; Wang, Y. Chin. J. Chem . 2011, 29, 223.

(13) (a) Chanawanno, K.; Holstrom, C.; Crandall, L. A.; Dodge, H.; Nemykin, V. N.; Herrick, R. S.; Ziegler, C. J. Dalton Trans. 2016, 45, 14320; (b) Chanawanno, K.; Holstrom, C.; Nemykin, V. N.; Herrick, R. S.; Ziegler, C. J. ChemistrySelect 2016, 1, 6438; (c) Chanawanno, K.; Blesener, T. S.; Schrage, B. R.; Nemykin, V. N.; Herrick, R. S.; Ziegler, C. J. J. Organomet. Chem. 2018, 870, 121

(14) Weinmayr, V. J. Am. Chem. Soc. 1955, 77, 3009.

(15) Nesmeyanov, A. N.; Perevalova, É. G.; Churanov, S. S. Dokl. Akad. Nauk SSSR 1958, 114, 335

(16) Knox, G. R.; Pauson, P. L. J. Chem. Soc. 1958, 692

(17) Falk, H.; Krasa, C.; Schlögl, K. Monatsh. Chem. 1969, 100, 1552.

(18) Nesmeyanov, A. N.; Perevalova, É. G.; Churanov, S. S.; Nesmeyanova, O. A. Dokl. Akad. Nauk SSSR 1958, 119, 949.

(19) Slocum, D. W.; Achermann, W. Synth. React. Inorg. Met.-Org. Chem. 1982, 12, 397.

(20) Cox, R. L.; Schneider, T. W.; Koppang, M. D. Anal. Chim. Acta 1992, 262, 145.

(21) Wen, M.; Erb, W.; Mongin, F.; Halauko, Y. S.; Ivashkevich, O. A.; Matulis, V. E.; Roisnel, T.; Dorcet, V. Organometallics 2021, Submitted.

(22) (a) Woolven, H.; González-Rodríguez, C.; Marco, I.; Thompson, A. L.; Willis, M. C. Org. Lett. 2011, 13, 4876; (b) Deeming, A. S.; Russell, C. J.; Willis, M. C. Angew. Chem. Int. Ed. 2015, 54, 1168.

(23) (a) Emmett, E. J.; Hayter, B. R.; Willis, M. C. Angew. Chem. Int. Ed. 2013, 52, 12679; (b) Deeming, A. S.; Russell, C. J.; Hennessy, A. J.; Willis, M. C. Org. Lett. 2014, 16, 150.

(24) Lenstra, D. C.; Vedovato, V.; Ferrer Flegeau, E.; Maydom, J.; Willis, M. C. Org. Lett. 2016, 18, 2086.

(25) Lo, P. K. T.; Oliver, G. A.; Willis, M. C. J. Org. Chem. 2020, 85, 5753.

(26) Sanders, R.; Mueller-Westerhoff, U. T. J. Organomet. Chem. 1996, 512, 219.

(27) Waldmann, C.; Schober, O.; Haufe, G.; Kopka, K. Org. Lett. 2013, 15, 2954.

(28) Kanzian, T.; Nigst, T. A.; Maier, A.; Pichl, S.; Mayr, H. Eur. J. Org. Chem. 2009, 2009, 6379.

(29) During the writing of this manuscript, another example of ferrocenesulfonamide diastereoselective deprotolithiation was reported February, the $19^{\text {th }}$; see: Ravutsov, M.; Dobrikov, G. M.; Dangalov, M.; Nikolova, R.; Dimitrov, V.; Mazzeo, G.; Longhi, G.; Abbate, S.; Paoloni, L.; Fusè, M.; Barone, V. Organometallics 2021, DOI: 10.1021/acs.organomet.0c00712. 
(30) (a) Marquarding, D.; Klusacek, H.; Gokel, G.; Hoffmann, P.; Ugi, I. J. Am. Chem. Soc. 1970, 92, 5389; (b) Rebière, F.; Riant, O.; Ricard, L.; Kagan, H. B. Angew. Chem. Int. Ed. Engl. 1993, 32, 568; (c) Riant, O.; Samuel, O.; Kagan, H. B. J. Am. Chem. Soc. 1993, 115, 5835; (d) Richards, C. J.; Damalidis, T.; Hibbs, D. E.; Hursthouse, M. B. Synlett 1995, 1995, 74; (e) Sammakia, T.; Latham, H. A. J. Org. Chem. 1995, 60, 6002; (f) Sammakia, T.; Latham, H. A.; Schaad, D. R. J. Org. Chem. 1995, 60, 10; (g) Riant, O.; Samuel, O.; Flessner, T.; Taudien, S.; Kagan, H. B. J. Org. Chem. 1997, 62, 6733; (h) Riant, O.; Argouarch, G.; Guillaneux, D.; Samuel, 0.; Kagan, H. B. J. Org. Chem. 1998, 63, 3511.
(31) Burchat, A. F.; Chong, J. M.; Nielsen, N. J. Organomet. Chem. 1997, 542, 281.

(32) Gottlieb, H. E.; Kotlyar, V.; Nudelman, A. J. Org. Chem. 1997, 62, 7512.

(33) Boev, V. I.; Osipenko, A. S.; Dombrovskii, A. V. Zh. Obshch. Khim. 1977, 47.

(34) Wang, S.; Li, Y.; Yang, X.; Shi, S. Fenxi Huaxue 1997, 25, 341.

(35) Soltani Rad, M. N.; Khalafi-Nezhad, A.; Asrari, Z.; Behrouz, S.; Amini, Z.; Behrouz, M. Synthesis 2009, 2009, 3983.

(36) Harmata, M.; Zheng, P.; Huang, C.; Gomes, M. G.; Ying, W.; Ranyanil, K.O.; Balan, G.; Calkins, N. L. J. Org. Chem. 2007, 72, 683. 